\title{
Impacts of mean annual air temperature change on a regional permafrost probability model for the southern Yukon and northern British Columbia, Canada
}

\author{
P. P. Bonnaventure ${ }^{1,2}$ and A. G. Lewkowicz ${ }^{2}$ \\ ${ }^{1}$ Department of Geography, Queen's University, Kingston, Canada \\ ${ }^{2}$ Department of Geography, University of Ottawa, Ottawa, Canada \\ Correspondence to: P. P. Bonnaventure (philip.bonnaventure@queensu.ca) \\ Received: 12 September 2012 - Published in The Cryosphere Discuss.: 24 October 2012 \\ Revised: 13 March 2013 - Accepted: 9 May 2013 - Published: 19 June 2013
}

\begin{abstract}
Air temperature changes were applied to a regional model of permafrost probability under equilibrium conditions for an area of nearly $0.5 \times 10^{6} \mathrm{~km}^{2}$ in the southern Yukon and northwestern British Columbia, Canada. Associated environmental changes, including snow cover and vegetation, were not considered in the modelling. Permafrost extent increases from $58 \%$ of the area (present day: 19712000) to $76 \%$ under a $-1 \mathrm{~K}$ cooling scenario, whereas warming scenarios decrease the percentage of permafrost area exponentially to $38 \%(+1 \mathrm{~K}), 24 \%(+2 \mathrm{~K}), 17 \%(+3 \mathrm{~K}), 12 \%$ $(+4 \mathrm{~K})$ and $9 \%(+5 \mathrm{~K})$ of the area. The morphology of permafrost gain/loss under these scenarios is controlled by the surface lapse rate (SLR, i.e. air temperature elevation gradient), which varies across the region below treeline. Areas that are maritime exhibit SLRs characteristically similar above and below treeline resulting in low probabilities of permafrost in valley bottoms. When warming scenarios are applied, a loss front moves to upper elevations (simple unidirectional spatial loss). Areas where SLRs are gently negative below treeline and normal above treeline exhibit a loss front moving up-mountain at different rates according to two separate SLRs (complex unidirectional spatial loss). Areas that display high continentally exhibit bidirectional spatial loss in which the loss front moves up-mountain above treeline and down-mountain below treeline. The parts of the region most affected by changes in MAAT (mean annual air temperature) have SLRs close to $0 \mathrm{~K} \mathrm{~km}^{-1}$ and extensive discontinuous permafrost, whereas the least sensitive in terms of areal loss are sites above the treeline where permafrost presence is strongly elevation dependent.
\end{abstract}

\section{Introduction}

Anthropogenically induced global climate change is expected to be magnified in arctic and subarctic areas (IPCC 2007; ACIA, 2005) and its effects are predicted to be particularly important on the cryosphere (ACIA, 2005). Impacts on permafrost, defined as earth materials which remain at or below a temperature of $0^{\circ} \mathrm{C}$ for two or more consecutive years (ACGR, 1988), are not known as precisely as climate change effects on sea ice and glaciers, in part due to incomplete or inadequate baseline information. Given that permafrost is the only element of the cryosphere on which people live yearround, it is essential that the ramifications and the potential risks associated with permafrost change under a warming climate become better understood.

Permafrost distribution at the regional and continental scales is strongly related to the mean annual air temperature (MAAT). However, other factors are also important (Shur and Jorgensen, 2007; Gruber and Haeberli, 2009), including elevation, depth and duration of snow cover, slope, aspect, geology and vegetation (Lewkowicz and Ednie, 2004; Lewkowicz and Bonnaventure, 2008; Bonnaventure and Lewkowicz, 2008, Gruber and Haeberli, 2009). As the polar amplification of climate change continues, terrain within the discontinuous permafrost zones where permafrost is warm and hence sensitive, is likely to undergo considerable change (Romanovsky et al., 2010; Smith et al., 2010).

The discontinuous permafrost zones of the Cordillera in northwestern Canada include areas that are economically important for resource industries and several major resource infrastructure projects are currently under development. This mountainous region also includes more than 20 communities 
with a total population of 25000 . The range of potential effects of climate change identified for this and other permafrost regions include warming of ground temperatures at the surface and at depth (IPCC, 2007; ACIA, 2005), increasing active layer thickness (Haeberli et al., 1993; Burn and Zhang, 2010; SWIPA, 2012; Bonnaventure and Lamoureux, 2013), basal thaw resulting in permafrost thinning (Harris et al., 2001; Woo et al., 2008), runoff changes (Woo et al., 2008), and the development of thermokarst features (Harris et al., 2001; Woo et al., 2008). Natural hazards associated with permafrost degradation (Kääb, 2008) may also develop as climate change will affect permafrost slopes, possibly generating or enhancing mass movements such as creeprelated processes, rockslides, rock falls, mudslides, and active layer detachment failures (Evans and Clague, 1994; Harris et al.,2001; Lewkowicz and Harris, 2005; Dorren, 2003; Lipovsky et al., 2006; Haeberli et al., 2006; Kääb, 2008).

The goal of this paper is to predict potential changes to permafrost extent for the southern half of the Yukon and extreme northern British Columbia when MAAT shifts of $-1 \mathrm{~K}$ to $+5 \mathrm{~K}$ are applied. Although other environmental factors, such as snow and vegetation, significantly influence permafrost distribution in the discontinuous zones (e.g. Smith and Riseborough, 2002) and are expected to alter in the future (e.g. IPCC, 2007), the model cannot take such changes into account. This paper is based on perturbing the mean annual air temperature field in a regional model previously developed to show the probability of permafrost under current climatic conditions (Bonnaventure et al., 2012b). The objective of the scenario-based modelling presented here is to reveal the degree and spatial pattern of potential permafrost loss, highlighting how this varies across the study region.

\section{Study region}

The study region extends from $59^{\circ} \mathrm{N}$ to $65^{\circ} \mathrm{N}$ and from $141^{\circ} \mathrm{W}$ to $123^{\circ} 5^{\prime} \mathrm{W}$, covering approximately $490000 \mathrm{~km}^{2}$ (Fig. 1). The region is part of the Cordilleran orogen geological grouping, comprising large mountain belts of deformed and metamorphosed sedimentary and volcanic rocks, mainly of the Phanerozoic and Proterozoic ages (Wahl et al., 1987; Eyles and Miall, 2007). During the Wisconsinan glacial maximum, the southern and central portions of the study area were covered by the thick ice masses of the Cordilleran ice sheet whereas the northwestern portion around Dawson was unglaciated (Duk-Rodkin, 1996).

Elevations range from $250 \mathrm{~m}$ a.s.l. in the Yukon River valley to higher than $5000 \mathrm{~m}$ a.s.l. in the St. Elias Mountains. The region encompasses all terrestrial permafrost zones, from isolated patches in the southwest to continuous in the most northerly areas (Heginbottom et al., 1995).

The entire region is in the Boreal Cordillera ecozone, which is characterized by mountain ranges with many lofty peaks and extensive plateaus. The climate of the region is

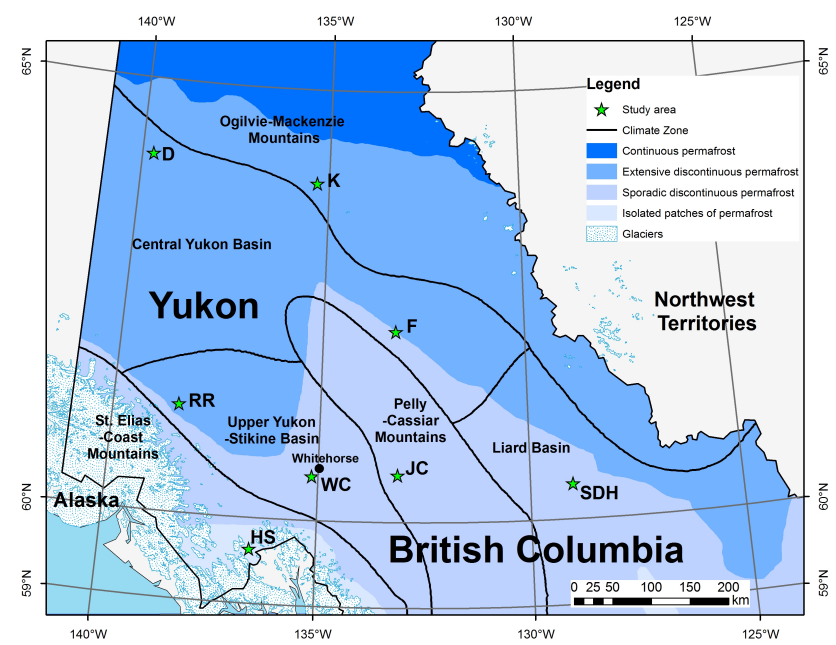

Fig. 1. Map of the study region showing intensive modelling sites (see Bonnaventure et al., 2012b) in relation to permafrost zones (Heginbottom et al., 1995) and climatic regions (Wahl et al., 1987). JC: Johnson's Crossing, SDH: Sa Dena Hes, F: Faro, K: Keno, D: Dawson, RR: Ruby Range, HS: Haines Summit and WC: Wolf Creek.

mainly subarctic continental, with long, cold winters and short, warm summers, varying with elevation and mountainside orientation (Natural Resources Canada, 2010). MAAT ranges from about $5{ }^{\circ} \mathrm{C}$ in the extreme southwest to $<-10^{\circ} \mathrm{C}$ on the highest peaks (Lewkowicz et al., 2012). The region can be sub-divided into six climatic regions largely based on physiography (Fig. 1), but climatic gradients are relatively gentle except in the southwest where precipitation totals $3500 \mathrm{~mm} \mathrm{yr}^{-1}$ on the Alaskan coast, decreasing to $400 \mathrm{~mm} \mathrm{yr}^{-1}$ on the leeward side of the St. EliasCoast Mountains. Continentality increases northward and eastward. Annual precipitation away from the St. EliasCoast Mountains ranges between about 300 and $400 \mathrm{~mm}$ with the highest amounts in the Liard Basin climatic region (Wahl et al., 1987). The entire study region experiences winter-time inversions in surface lapse rates (SLR) through the forested zone (Lewkowicz and Bonnaventure, 2011). The results of inverted SLRs on an annual basis are increased permafrost probabilities in valley bottoms in areas of high continentality while in more maritime environments, SLRs are gentle but normal, making permafrost less common at low elevations. In parts of northern British Columbia, therefore, a lower permafrost elevational limit exists (Lewkowicz et al., 2012). Changes in SLR from below to above treeline have been observed at widely spaced sites over multiple years, but their cause remains unknown (Lewkowicz and Bonnaventure, 2011).

Vegetation in the region comprises boreal forest with coniferous trees and some boreal broadleaf trees in lowland areas, while sub-alpine forest, shrubs, alpine tundra, barren patches, and exposed rock occur progressively at higher 
elevations (Wahl et al., 1987; Kremer et al., 2011). The northernmost portion of the study area is very close to an ecosystem boundary where vegetation begins to transition to arctic tundra with alpine sedges, grasses and shrubs dominating (Wahl et al., 1987).

\section{Methods}

\subsection{Regional permafrost model development}

The regional model (RM) of permafrost probability (Bonnaventure et al., 2012b) is an empirical-statistical model, which relates field data collected in both winter and summer to variables calculated from a digital elevation model (DEM; resolution $30 \mathrm{~m} \times 30 \mathrm{~m}$ ) in a geographic information system (GIS). The relationship between permafrost distribution and elevation in this area is complex and valley bottoms are at relatively high elevations (typically $600-700 \mathrm{~m}$ a.s.1.) where permafrost may be present. Here we provide a summary of the main points of the model as its full derivation has been described previously (Bonnaventure et al., 2012b).

The model's main field inputs are more than 2000 basal temperature of snow (BTS) and ground-truthing data points collected in seven intensive study sites within the region (Fig. 1) from 2001 to 2009. BTS measurements provide point indications of permafrost likelihood that can be related statistically to factors such as elevation, equivalent elevation (e.g. Lewkowicz and Bonnaventure, 2011), slope, and potential incoming solar radiation (PISR). BTS measurements were calibrated using checks of the physical presence or absence of frozen ground in the late summer, allowing permafrost probability to be calculated across a spatial surface using logistic regression (e.g. Lewkowicz and Ednie, 2004). The calculated probabilities are for typical snow cover conditions and there can be considerable sub-grid cell variability where sites are locally blown clear of snow (higher probability of permafrost) or accumulate early and deep snow covers (lower probability of permafrost) (Lewkowicz and Ednie, 2004). Individual permafrost probability models were created for the intensive study sites, which ranged in size from $200-1500 \mathrm{~km}^{2}$ (Fig. 1). Interpolation across the region was undertaken using a blended distance decay function (Bonnaventure et al., 2012b).

A novel aspect of the regional model is its use of equivalent elevation (Lewkowicz and Bonnaventure, 2011), not actual elevation, as the primary DEM-derived predictive variable to represent trends in MAAT. In the calculation of equivalent elevation, the numerical elevations of grid cells below treeline are changed to take into account weakened or reversed SLRs in the forest compared to the strongly negative SLRs above treeline. Equivalent elevation is calculated from

$Z_{x}^{\prime}=Z_{\mathrm{t}}-\left(Z_{\mathrm{t}}-Z_{x}\right) \times \frac{L_{1}}{L_{2}}$

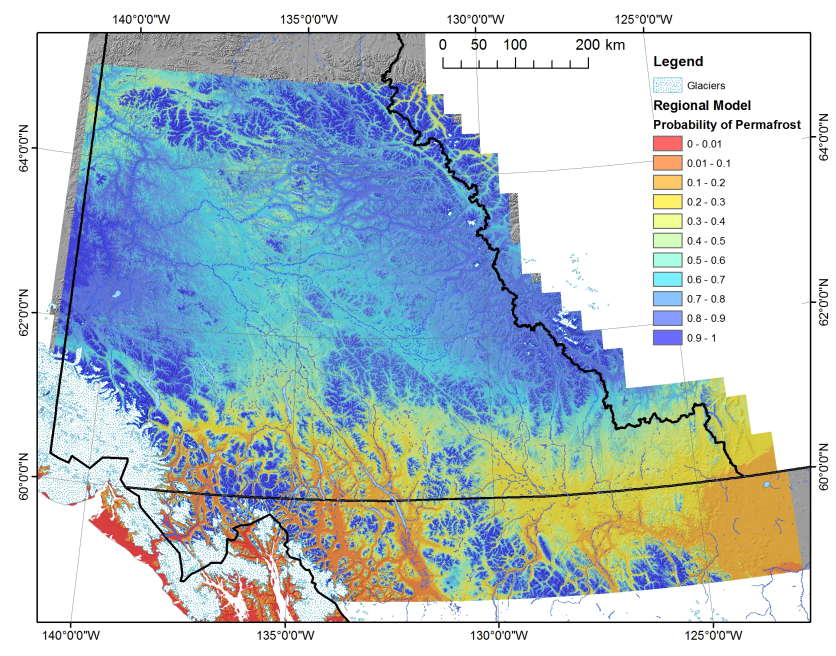

Fig. 2. Regional model permafrost probability map for presentday conditions (1971-2000). Permafrost underlies 58\% of the unglaciated territory (Bonnaventure et al., 2012b).

where $Z_{x}^{\prime}$ is equivalent elevation (ma.s.l.), $Z_{t}$ is the elevation of treeline (m a.s.l.), $Z_{x}$ is actual grid cell elevation (ma.s.l.), $L_{1}$ is the measured or predicted SLR below treeline $\left(\mathrm{K} \mathrm{km}^{-1}\right)$ and $L_{2}$ is the SLR above treeline. Depending on the value of $L_{1}$, grid cells that are well below treeline may be increased significantly in elevation, areas close to treeline are changed very little and areas above treeline remain unchanged.

The derivation of the equivalent elevation surface for each grid cell in the region is described in detail in Lewkowicz and Bonnaventure (2011). The most important relationship was between $L_{1}$ and the degree of continentality of a site as expressed by the difference between the January and July mean monthly air temperatures. The strength of this relationship permitted standard weather station data to be used to estimate $L_{1}$ at multiple locations in the region and ultimately to develop a polynomial trend surface of $L_{1}$ values.

$L_{2}$ was assumed to be uniformly $-6.5 \mathrm{~K} \mathrm{~km}^{-1}$. Field measurements give $L_{2}$ values of $-6.4 \mathrm{~K} \mathrm{~km}^{-1}$ at Haines Summit (the most maritime site), $-6.1 \mathrm{~K} \mathrm{~km}^{-1}$ at Wolf Creek (a moderately continental site) and $-6.8 \mathrm{~K} \mathrm{~km}^{-1}$ at Dawson (the most continental site). Given the limited information available and the small range in measured values, assuming a uniform value for $L_{2}$ appeared to be the best solution. While this introduces potentially greater uncertainty as elevations increase above treeline, sites at these elevations are already modelled as having very high permafrost probabilities so that the impact of any inaccuracy is minimized.

The regional model shows that $58 \%$ of the study region is underlain by permafrost under current conditions (19712000 climate normals) (Fig. 2; Bonnaventure et al., 2012b). These predictions cannot be fully validated because a spatially distributed data set of permafrost presence/absence does not exist for the region. However, the regional model 
predictions have been compared to: (1) field observations in the Sa Dena Hes area that were not used in the derivation of the regional model (Bonnaventure and Lewkowicz, 2012a); (2) permafrost zone boundaries on the national permafrost map of Canada (Heginbottom et al., 1995); (3) a database of Yukon rock glaciers (Page, 2009); and (4) a series of temperature measurements in instrumented boreholes (Global Terrestrial Network for Permafrost, 2011). The results suggest that the model may slightly over-predict permafrost probabilities where they are $>0.5$ and slightly under-predict at probabilities $<0.5$. However, the predicted trends reflect observed probability patterns (Bonnaventure et al., 2012b).

\subsection{Regional model perturbation for climate change scenarios}

A range of MAAT increases from $+1 \mathrm{~K}$ to $+5 \mathrm{~K}$ were investigated based on IPCC (Intergovernmental Panel on Climate Change) and ACIA (Arctic Climate Impact Assessment) predictions for the upcoming century. Scenario temperature changes in this paper are indicated in degrees Kelvin (K) in order to avoid confusion with MAATs which are stated in degrees Celsius. A scenario approach was favoured over applying global or regional climate model predictions which suffer from inadequate representation of the topography in the Yukon (see Burn, 1994). Permafrost conditions were also investigated under a cooler MAAT $(-1 \mathrm{~K})$ that may be representative of conditions during the Little Ice Age (LIA; Farnell et al., 2004). A $-1 \mathrm{~K}$ air temperature change was chosen because dendrochronological results for the region indicate that maximum temperatures during summers from $1684-1850 \mathrm{AD}$ were generally $0-1 \mathrm{~K}$ lower than in the 1961-1990 reference period (Youngblut and Luckman, 2008). Since summer temperatures may exhibit less variability than annual values, it is possible that the $-1 \mathrm{~K}$ change is conservative for LIA conditions.

The goal of imposing the climate change scenarios is to examine the sensitivity of the permafrost model response over the long-term to a change in MAAT. The modelling is for equilibrium conditions and therefore does not take into account the rate at which the change in climate might occur, nor the lag times associated with permafrost thaw.

Changes in MAAT were simulated in the spatial model by uniformly increasing the values of equivalent elevation in the transformed DEM for cooling scenarios or decreasing them for warming scenarios (Janke, 2005; Bonnaventure and Lewkowicz, 2010), and then running the model to produce an altered BTS surface. This affects the predicted permafrost probabilities that are calibrated with the non-linear logistic regression coefficients determined for the 1971-2000 base case. A change of $1 \mathrm{~K}$ is represented by an increase or decrease in the equivalent elevation surface of $154 \mathrm{~m}$. Even though the change is uniformly applied across the region, this results in differential responses that depend on the SLRs below treeline. This methodology has the advantage of preserv-

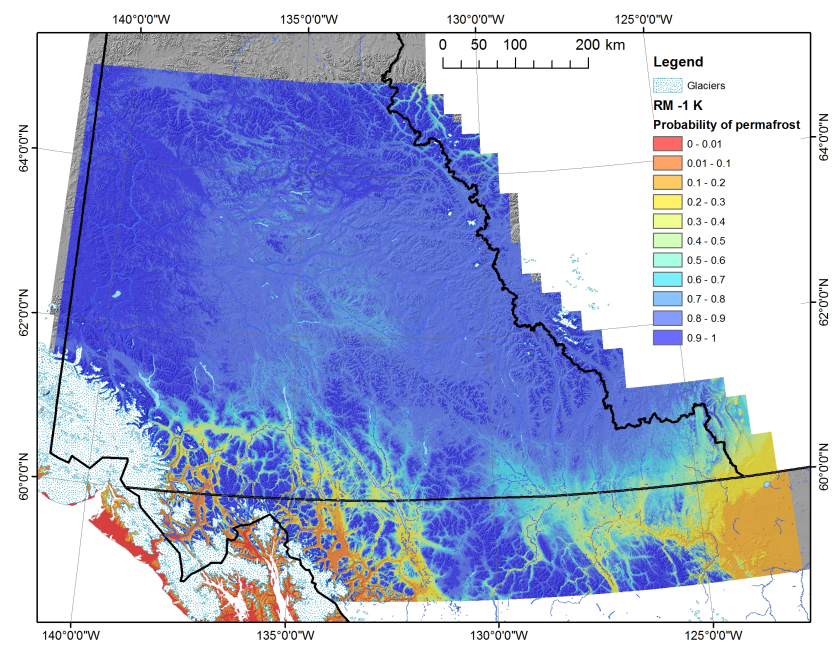

Fig. 3. Regional model permafrost probability map under a $-1 \mathrm{~K}$ climate change scenario, possibly corresponding to LIA conditions. Permafrost underlies $76 \%$ of the region under this scenario.

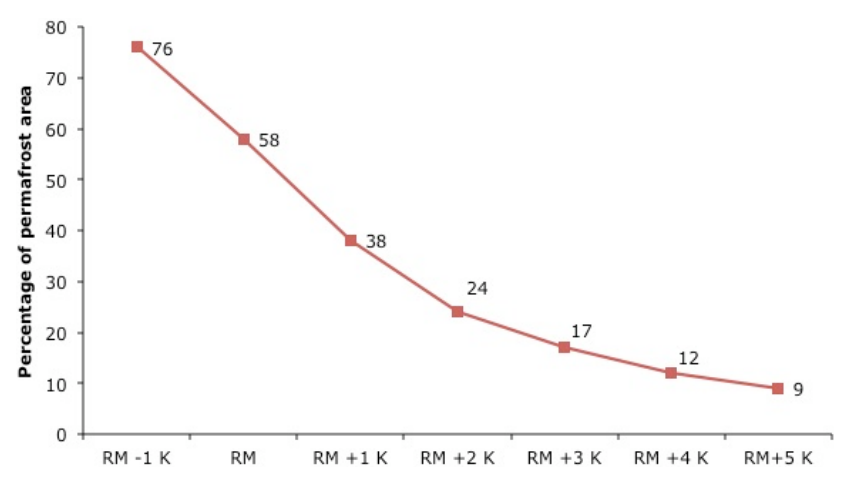

Fig. 4. Modelled percentage area underlain by permafrost under equilibrium conditions for the entire region under the climate modelling scenarios.

ing all elements of the spatial model for a given area such as aspect, shading and slope, as well as the specific relationships that exist between changes in elevation and BTS values.

\section{Results}

Each change of MAAT from the RM base case has a significant impact on the extent and distribution of permafrost in the region. In the RM $-1 \mathrm{~K}$ scenario (Fig. 3), the percentage area underlain by permafrost increases from 58 to $76 \%$ of the currently unglaciated territory. It is likely that the glaciated area would also expand if MAATs were $1 \mathrm{~K}$ lower than at present but this change is not represented and all scenarios use the same glacier extent. This modelling suggests that a major decrease in permafrost extent has probably occurred since the end of the LIA, especially in the southern and central portions of the region. 


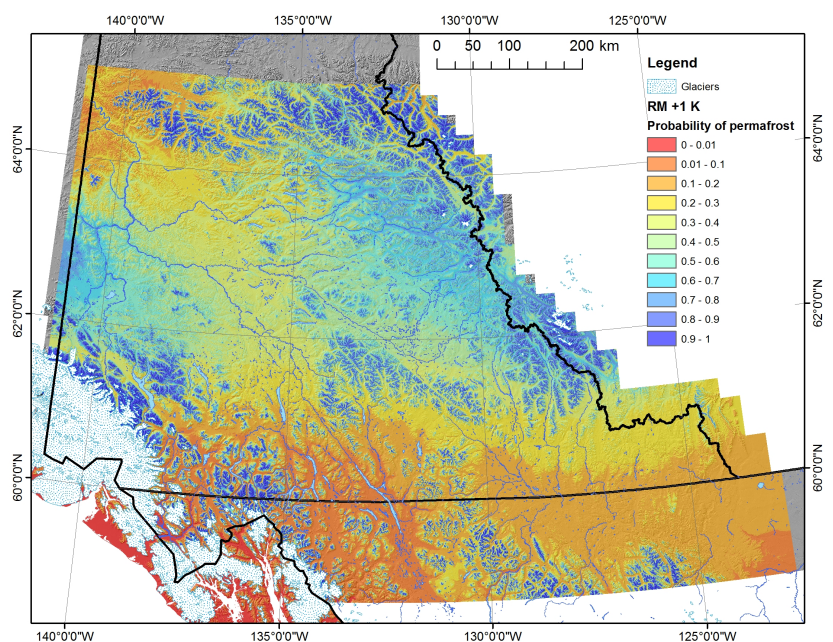

Fig. 5. Regional model permafrost probability map under a $+1 \mathrm{~K}$ climate change scenario. Permafrost underlies $38 \%$ of the region under this scenario.

Increases in MAAT result in a progressive decrease in permafrost extent, with the decline being approximately exponential (Fig. 4). The $+1 \mathrm{~K}$ change (Fig. 5) has the greatest impact, causing a decrease of $20 \%$ in the percentage area underlain by permafrost to $38 \%$. Therefore, according to the modelling, the region is slightly more sensitive to a change in MAAT at present than it will be in the future or than it was in the past. The RM $+2 \mathrm{~K}$ scenario (Fig. 6) reduces the permafrost area to $24 \%$ of the region and additional warming causes further declines. The largest modelled increase in MAAT, by $+5 \mathrm{~K}$, reduces overall permafrost extent to $9 \%$. Most of the region is then in the isolated patches of permafrost zone ( $0-10 \%$ permafrost) with only a part of the east-central region in the sporadic discontinuous zone (Fig. 7). In the western part of the RM $+5 \mathrm{~K}$ scenario, the highest peaks alone maintain permafrost probabilities $>0.1$.

The region was divided into four sub-regions (Extreme Southwest (ESW), South, Mid, and North) to examine how the distribution of permafrost responds to the climate scenarios in more detail. The spatial division was based on similarities in SLRs (Fig. 8). As would be expected, the North sub-region has the greatest percentage of permafrost, with progressively smaller fractions of the landscape affected in the Mid, South and ESW sub-regions (Fig. 9). The change trends for the North and Mid sub-regions are the same as for the region as a whole with the greatest difference in permafrost area between the RM and the RM + $1 \mathrm{~K}$ scenarios. In contrast, the South and ESW sub-regions exhibit their greatest changes between RM $-1 \mathrm{~K}$ and the RM base case. The North sub-region is the most sensitive overall, declining from $88 \%$ of the landscape underlain by permafrost for RM $-1 \mathrm{~K}$ to $11 \%$ for $\mathrm{RM}+5 \mathrm{~K}$ (Table 1 ).

The non-parallel lines in Fig. 9 indicate that the subregions exhibit differing gain/loss patterns as the climate sce-

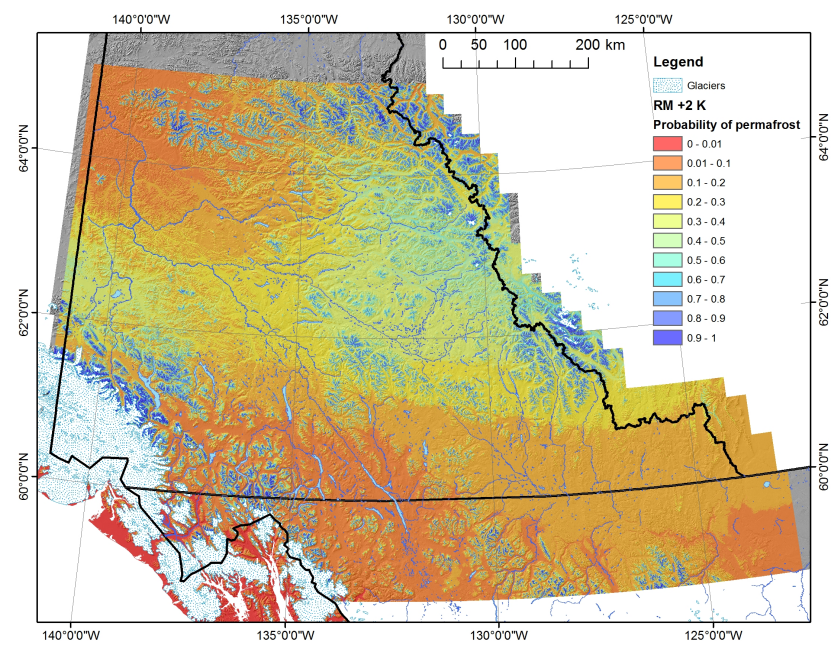

Fig. 6. Regional model permafrost probability map under $\mathrm{a}+2 \mathrm{~K}$ climate change scenario. Permafrost underlies $24 \%$ of the region under this scenario.

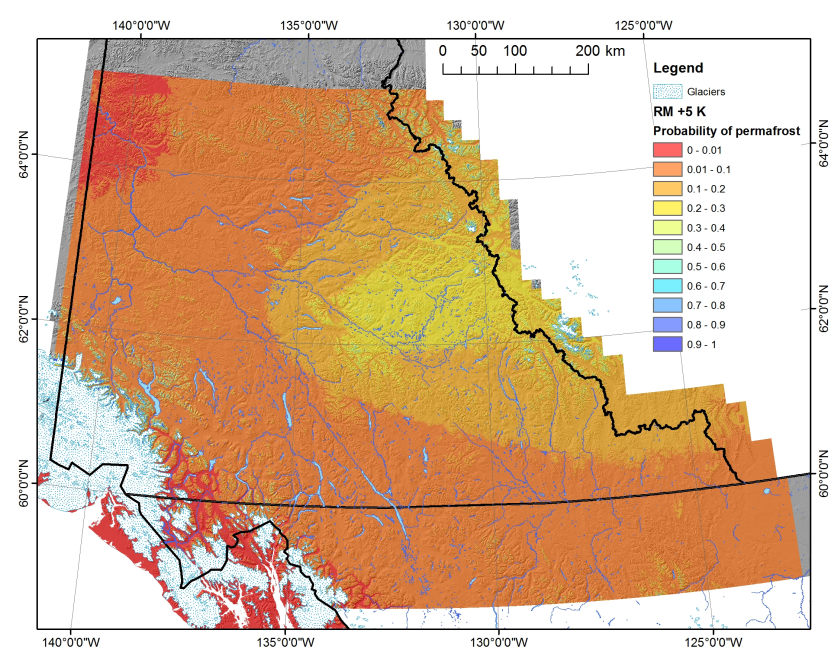

Fig. 7. Regional model permafrost probability map under $\mathrm{a}+5 \mathrm{~K}$ climate change scenario. Permafrost underlies $9 \%$ of the region under this scenario.

narios are imposed. These were examined using the distribution of grid cells in permafrost probability classes (Fig. 10). The ESW sub-region has a high percentage of cells with low probabilities $(<0.2)$, a mode at $<0.1$, very few cells through most of the probability range, and a secondary peak in distributions at probabilities $>0.8$ in all scenarios except RM $+5 \mathrm{~K}$. The pattern of gain/loss with increasing MAAT is straightforward as percentages at the lower end of the probability distribution increase while those at the higher probabilities decline.

In the South sub-region, the frequency distribution resembles that of the ESW but the primary mode is higher at $0.1-0.2$ for RM and the secondary mode at $>0.9$ is large enough to become the primary one for RM $-1 \mathrm{~K}$ (Fig. 10). 


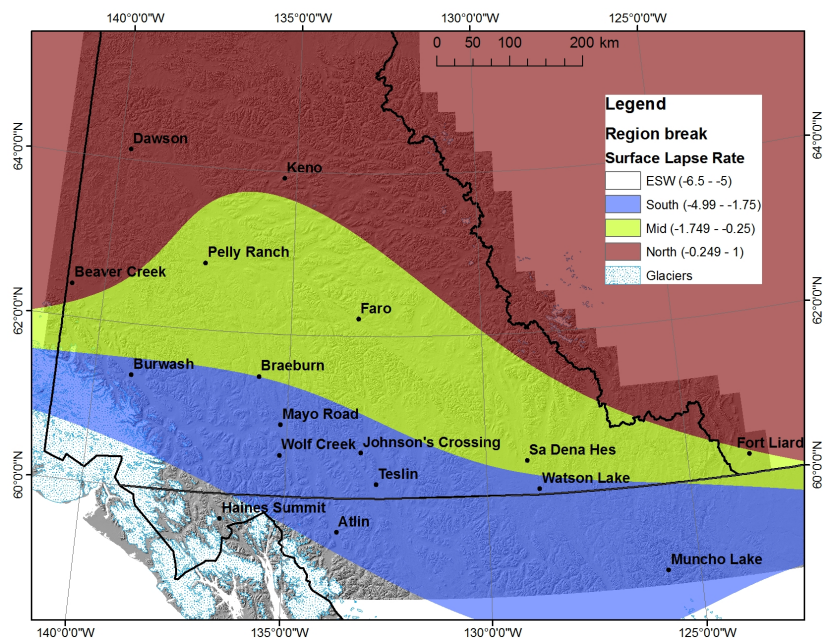

Fig. 8. Sub-regions based on common SLRs.

Table 1. Percentage area underlain by permafrost in each scenario by sub-region.

\begin{tabular}{llllll}
\hline Scenario & Region & North & Mid & ESW & South \\
\hline RM-1 K & 76 & 88 & 82 & 31 & 65 \\
RM & 58 & 75 & 63 & 22 & 42 \\
RM+1 K & 36 & 51 & 41 & 14 & 26 \\
RM+2 K & 24 & 32 & 27 & 9 & 17 \\
RM+3 K & 17 & 21 & 19 & 5 & 11 \\
RM+4 K & 12 & 15 & 15 & 3 & 8 \\
RM+5 K & 9 & 11 & 12 & 1 & 6 \\
\hline
\end{tabular}

In addition, there are significant percentages of cells in all the probability classes between the primary and secondary modes. As MAAT increases, the low probability modal class initially remains constant while increasing in magnitude, but in the RM $+2 \mathrm{~K}$ scenario the modal class switches to $<0.1$. As with the ESW sub-region, there is a progressive decline across all of the intermediate probability classes as MAAT increases.

In the Mid sub-region there is a single mode for each scenario which shifts to lower probabilities with each increase in MAAT, starting in the $0.8-0.9$ class for RM $-1 \mathrm{~K}$ and ending in the $<0.1$ class for the RM $+5 \mathrm{~K}$ scenario (Fig. 10). However, even under the $\mathrm{RM}+5 \mathrm{~K}$ scenario, there are significant groups of cells with modelled probabilities $>0.1$.

The mode in the $\mathrm{RM}-1 \mathrm{~K}$ scenario is $>0.9$ for the North sub-region and this shifts to between $0.8-0.9$ for the RM base case, with very few cells having probabilities $<0.5$ (Fig. 10). As warming is applied, the probability distribution becomes flatter with a mode that shifts to $0.2-0.3$ for the $\mathrm{RM}+1 \mathrm{~K}$ scenario, to $0.1-0.2$ for $\mathrm{RM}+2 \mathrm{~K}$ scenario and to $<0.1$ for the $\mathrm{RM}+5 \mathrm{~K}$ scenario. In summary, the results of the scenario modelling show that the spatial response of permafrost will be significant but heterogeneous, even without consid-

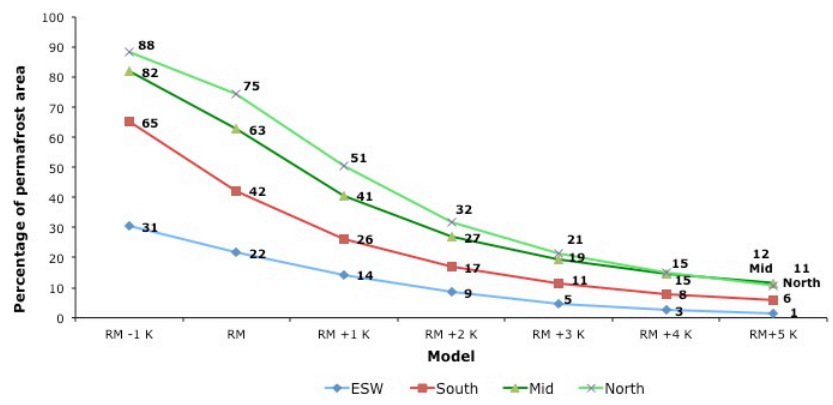

Fig. 9. Modelled percentage area underlain by permafrost under equilibrium conditions for each sub-region under the climate modelling scenarios.

eration of differential increases in MAAT, sub-grid-cell variability in snow depths, or variable response lag times. This heterogeneity relates to the spatial patterns of permafrost loss which are discussed below.

\section{Discussion}

Perturbing input variables to examine climate change impacts on permafrost models in mountain areas was undertaken previously for small areas (Janke, 2005; Bonnaventure and Lewkowicz, 2010). These models were primarily elevation based, and thus showed lower permafrost probabilities moving up-mountain as warming scenarios were applied. This response appears to be reasonable for areas above treeline where fixed SLRs can be used (e.g. Bonnaventure and Lewkowicz, 2010). However, much of the area covered by the regional model is below treeline and the modelling, therefore, must incorporate the effect of variable SLRs (Lewkowicz and Bonnaventure, 2011). The regional model is the only empirical statistical model to be derived for such a large area while retaining a resolution of $30 \mathrm{~m} \times 30 \mathrm{~m}$ and is the first to examine non-linear elevation based permafrost changes, as the coldest areas are not necessarily those at the highest elevations. The perturbation of the model allows for an understanding of permafrost loss morphology, which is important scientifically as well as for planning community adaptation and linear infrastructure-route planning.

The behaviour of the distribution of permafrost in each of the regional zones (Figs. 11-13) is essentially the product of the climate, which is generalized through the value of the SLR in the forest. Continental areas that have SLRs in the forest close to $0 \mathrm{~K} \mathrm{~km}^{-1}$ (little or no temperature change with elevation) have permafrost distributions that are elevation independent, whereas maritime areas whose SLRs approach normal $\left(-6.5 \mathrm{~K} \mathrm{~km}^{-1}\right)$ can be viewed as elevation dependent. In elevation-independent areas, a + $1 \mathrm{~K}$ scenario change can affect areas across a much greater band of elevations than will be the case for elevation-dependent areas. 

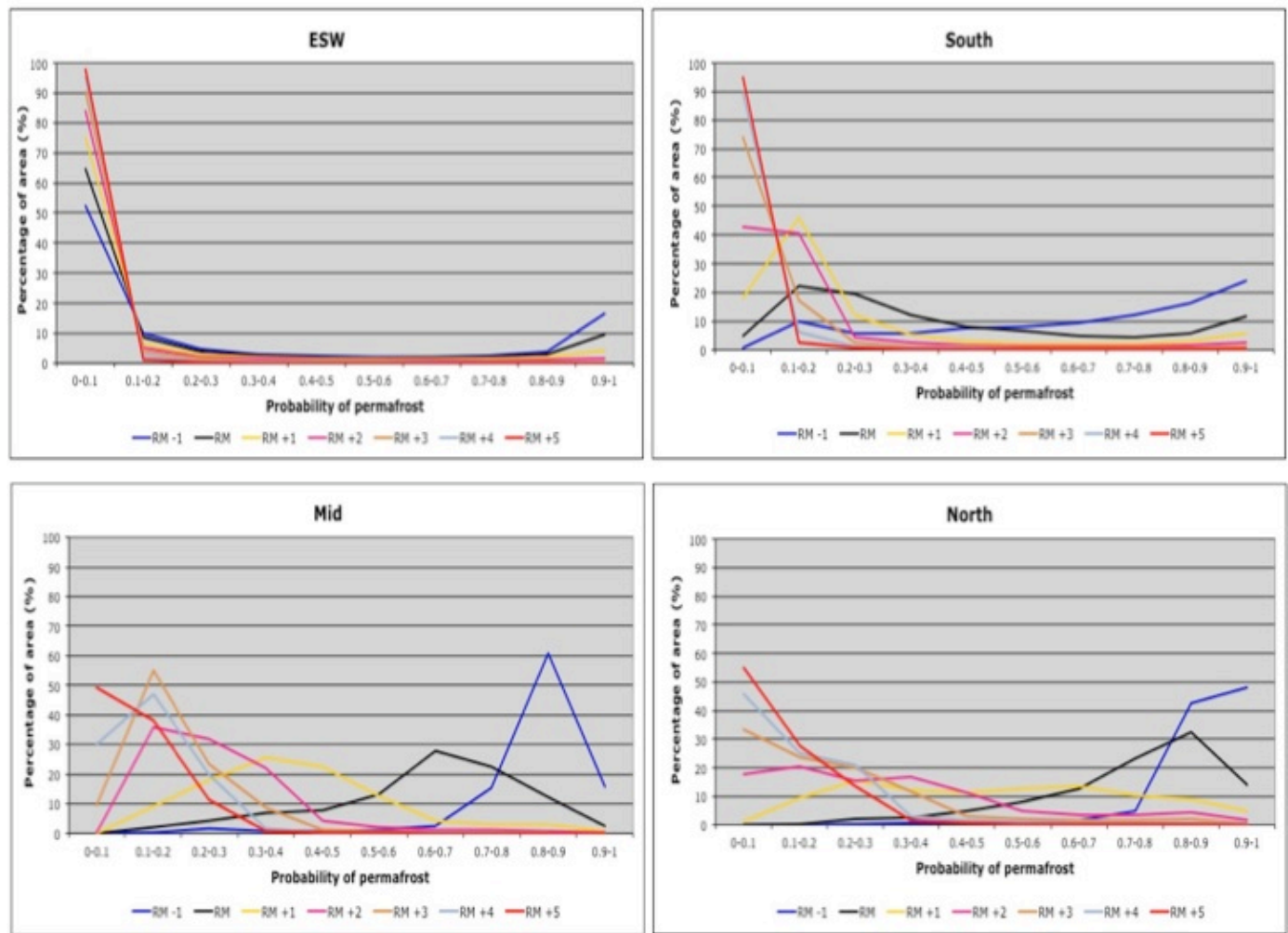

Fig. 10. Distribution of permafrost probabilities for each sub-region under the climate modelling scenarios. Permafrost probabilities are grouped into classes of 0.1 .

Table 2. Permafrost loss pattern summary by sub-region.

\begin{tabular}{|c|c|c|c|}
\hline $\begin{array}{l}\text { Loss } \\
\text { type }\end{array}$ & $\begin{array}{l}\text { Sub-region } \\
\text { affected }\end{array}$ & $\begin{array}{l}\text { SLR } \\
\text { range }\end{array}$ & $\begin{array}{l}\text { Relation to } \\
\text { elevation }\end{array}$ \\
\hline SUSL & ESW & $-6.5 \mathrm{~K} \mathrm{~km}^{-1}$ & Dependent \\
\hline CUSL & South \& Mid & $\begin{array}{l}<0 \text { to } \\
-6.5 \mathrm{~K} \mathrm{~km}^{-1}\end{array}$ & $\begin{array}{l}\text { More dependent closer } \\
\text { to }-6.5 \mathrm{~K} \mathrm{~km}^{-1} \text { and } \\
\text { approaching independent } \\
\text { as } 0 \mathrm{~K} \mathrm{~km}^{-1} \text { is approached }\end{array}$ \\
\hline BSL & North & $\left(>0 \mathrm{~K} \mathrm{~km}^{-1}\right)$ & Close to independent \\
\hline
\end{tabular}

\subsection{Loss morphology types}

Three different types of permafrost loss patterns can be identified: Simple unidirectional spatial loss, complex unidirectional spatial loss, and bidirectional spatial loss (Table 2).

Simple unidirectional spatial loss (SUSL) (Figs. 11 and 12) occurs in areas that have a normal SLR $\left(-6.5 \mathrm{~K} \mathrm{~km}^{-1}\right)$ both above and below treeline. These environments are located in the ESW sub-region and in the base case, have very low probabilities of permafrost $(0-0.1)$ in valley bottoms and up to treeline. Above treeline, probabilities increase with elevation and surpass those of continuous permafrost $(>0.9)$ at the highest elevations. When a warming scenario is applied, lower probabilities shift to higher elevations, a progressive reduction which can be termed a loss front. In an area of SUSL, the loss pattern resembles that produced in previous models, which are highly elevation dependent (e.g. Bonnaventure and Lewkowicz, 2010). A similar pattern would be expected for regions such as the European Alps (e.g. Gruber and Hoelzle, 2001) and the mountains of southern Norway (Isaksen et al., 2002). Areas that display SUSL in the regional model include the intensive study site of Haines Summit as well as the majority of the ESW where the largest 
Simple Unidirectional Spatial Loss (SUSL)
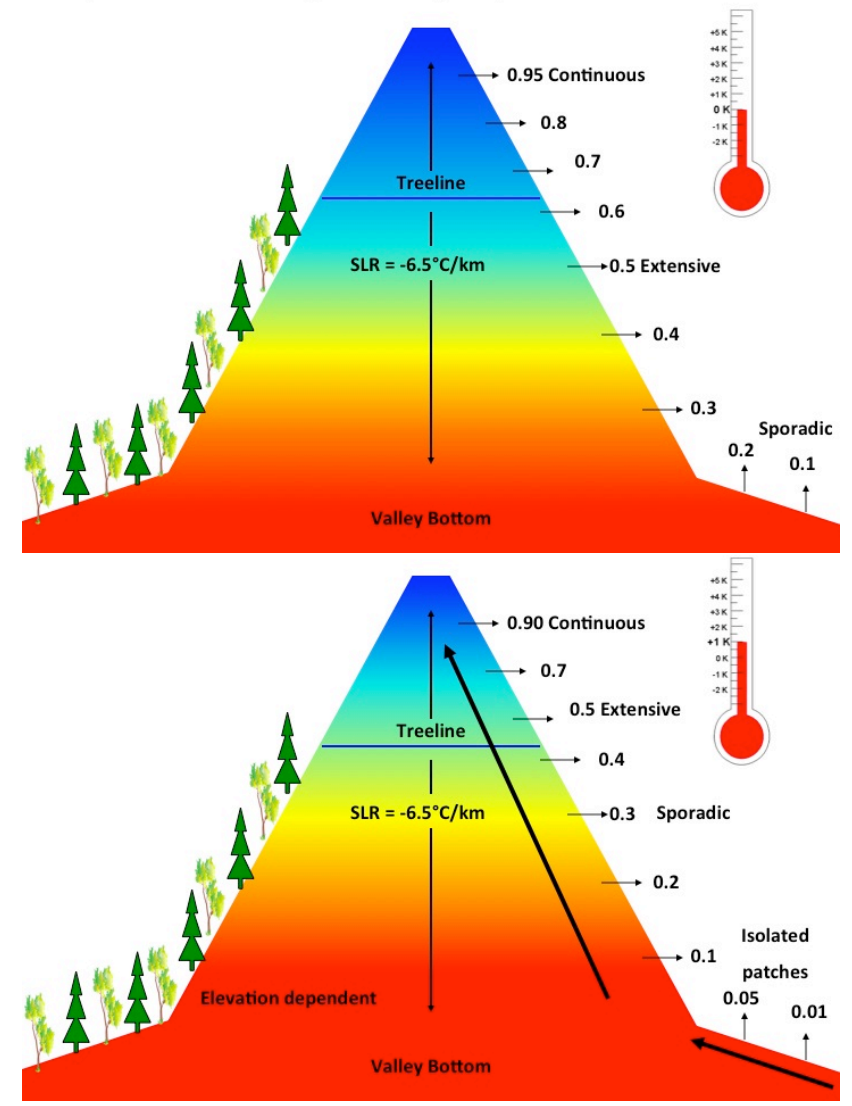

Fig. 11. (Upper) Conceptual diagram of permafrost probability variation in an area susceptible to simple unidirectional spatial loss; (lower) equilibrium permafrost probabilities following a warming scenario.

glaciated areas, the highest mountains and the most annual precipitation all occur (Figs. 11 and 12).

Complex unidirectional spatial loss (CUSL) (Figs. 12 and 13) develops in areas where the SLR is gentle below treeline (e.g. $-2.5 \mathrm{~K} \mathrm{~km}^{-1}$ ) and normal above treeline $\left(-6.5 \mathrm{~K} \mathrm{~km}^{-1}\right)$. When a warming scenario is applied, the loss front moves up the elevation bands below and above treeline but at two different rates. As discussed above, a low SLR makes an area less elevation dependent and potentially more sensitive to a change in MAAT. Assuming permafrost is present both above and below treeline, a given warming will affect the area below treeline over a larger elevation band than that above treeline. Consequently, the area of permafrost above treeline is more resistant to small changes in MAAT (e.g. $+1 \mathrm{~K})$. The Mid and South sub-regions are affected by CUSL and include the intensive study sites of Wolf Creek, Ruby Range, Johnson's Crossing, Sa Dena Hes and Faro.

Bidirectional spatial loss (BSL) is the most complex pattern as the loss front moves in two different directions (Figs. 12 and 14). BSL occurs where the SLR through the forest is inverted (positive), which in the modelled area is in the

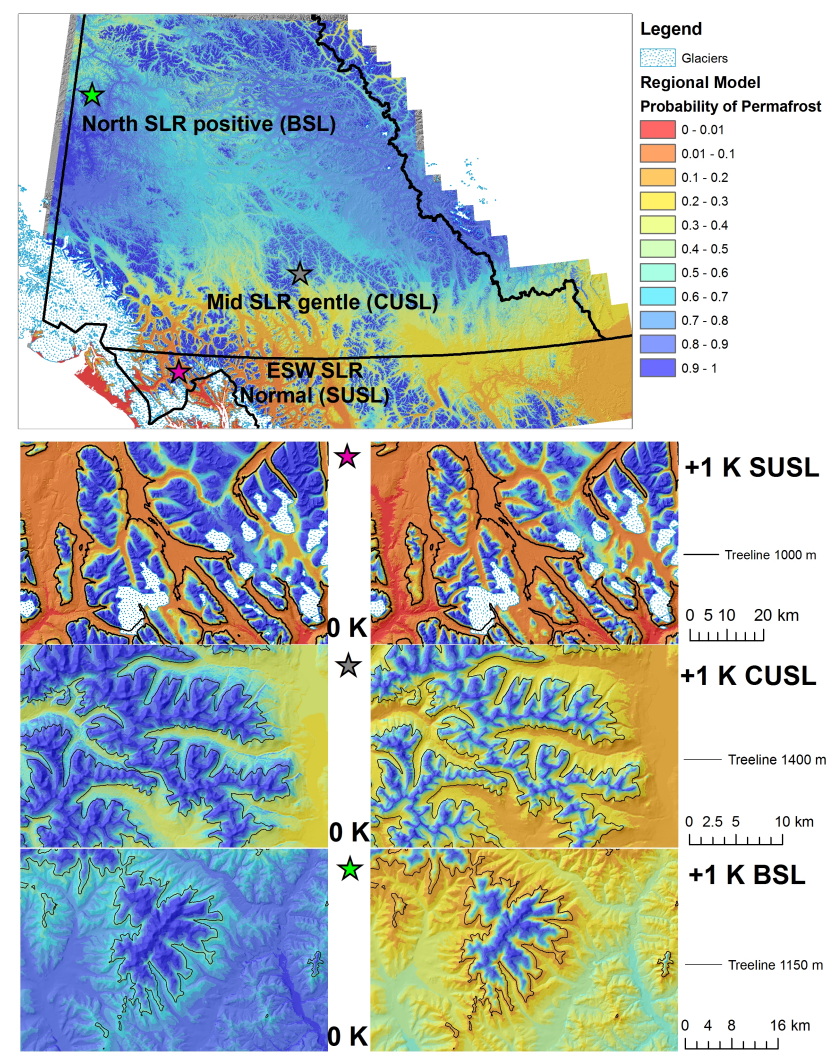

Fig. 12. Examples of modelled permafrost probabilities under RM and $\mathrm{RM}+1 \mathrm{~K}$ scenarios for three different locations and loss patterns. Upper map shows the locations of the examples in the paired lower maps.

most continental North sub-region. In areas of BSL the highest probabilities of permafrost are located in both the mountaintops above treeline and in the valley bottoms below treeline where cold air pools (Clements et al., 2003; Pagès and Miró, 2009; Lewkowicz and Bonnaventure, 2011). A warming scenario causes the loss front to move up-mountain from the treeline toward the highest elevations and simultaneously down-mountain below treeline towards the valley bottom. The area below treeline however, has an SLR much closer to $0 \mathrm{~K} \mathrm{~km}^{-1}$ which makes the area less elevation-dependent. Consequently it loses permafrost over a larger band of elevations than the area above treeline for the same change of MAAT. This makes the areas below treeline subject to BSL susceptible to small MAAT scenario changes. The study areas of Keno and Dawson are located within the areas subject to BSL which extend as far as Beaver Creek in the west.

The areas that are most susceptible to potential permafrost loss are those with SLRs close to $0 \mathrm{~K} \mathrm{~km}^{-1}$. Their distributions are elevation independent below treeline and when a scenario change is applied, all grid cells below treeline are prone to permafrost loss and essentially there is no loss front (Fig. 15). Areas with SLRs that are close to normal 
Complex Unidirectional Spatial Loss (CUSL)
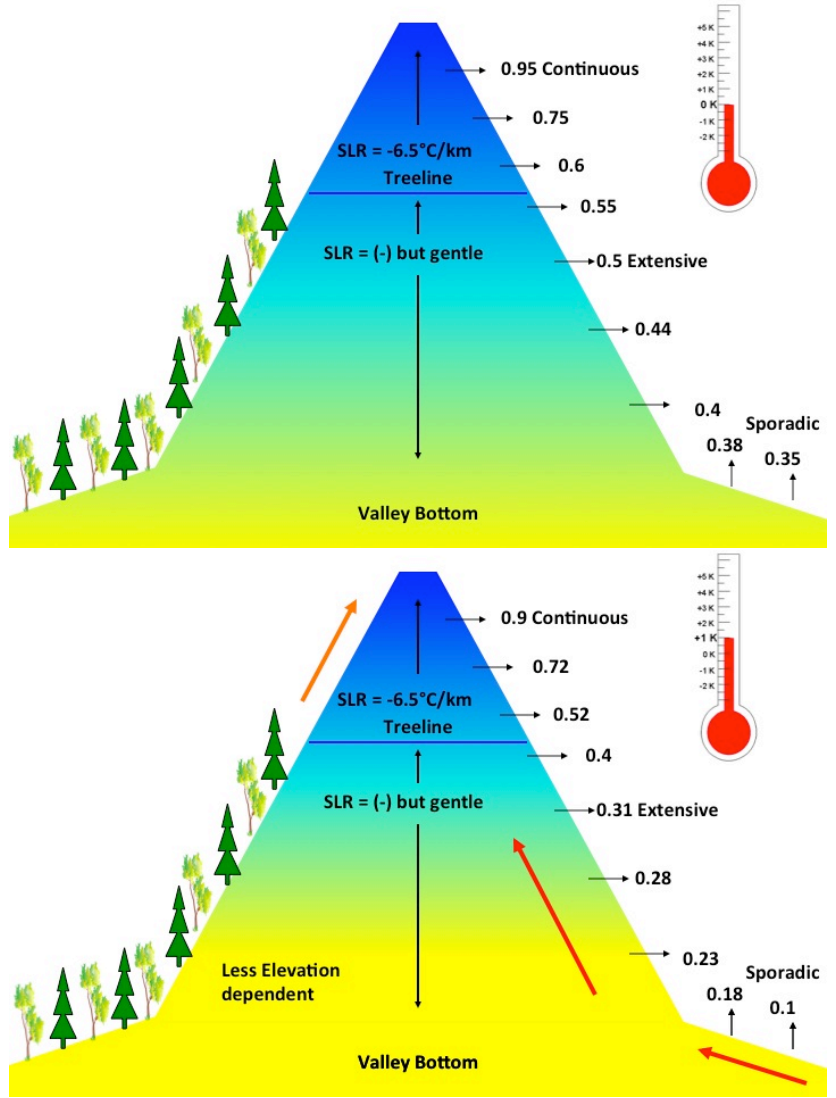

Fig. 13. (Upper) Conceptual diagram of permafrost probability variation in an area susceptible to complex unidirectional spatial loss; (lower) equilibrium permafrost probabilities following a warming scenario.

$\left(-6.5 \mathrm{~K} \mathrm{~km}^{-1}\right)$ as well as all areas above treeline are the most elevation dependent and will have a distinct loss front. In the model region, the areas that are most susceptible spatially also currently have high permafrost probabilities. Climate warming in the region should therefore elicit significant change in geomorphic, hydrologic and ecosystem functioning above and below treeline due to permafrost loss (Kneisel et al., 2007; Kääb, 2008). Additional impacts may relate to vegetation change (Jorgensson et al., 2001), alterations to carbon cycling and the emission of greenhouse gases as frozen organic material thaws (Tarnocai et al., 2009; Hugelius et al., 2010; O'donnell et al., 2011).

\subsection{Model limitations}

The patterns and amounts of permafrost loss represent the potential changes under equilibrium conditions and do not take transient effects or lag times into account. Changes in climate or surface conditions including snow cover (e.g. Burn and Nelson 2006; Lawrence et al., 2008) may not lead to permafrost thaw for decades or longer. Ice-rich permafrost sites

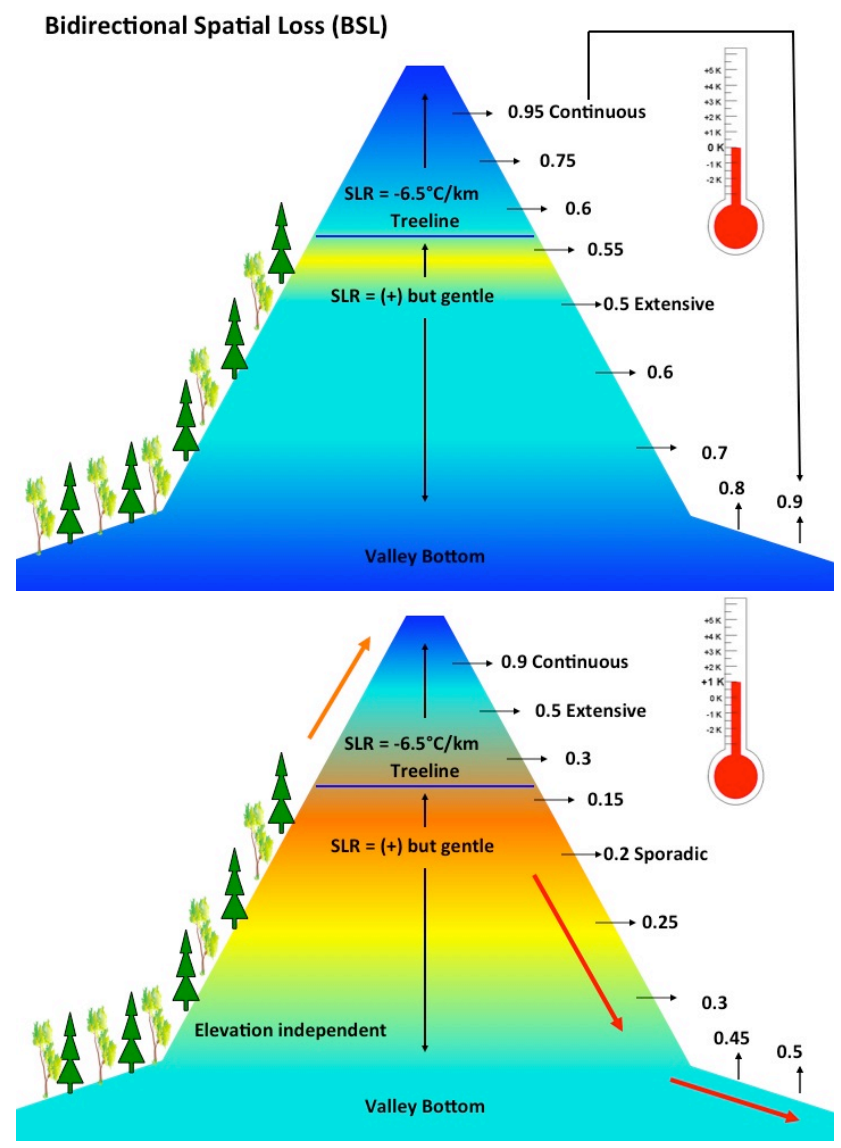

Fig. 14. (Upper) Conceptual diagram of permafrost probability variation in an area susceptible to bidirectional spatial loss; (lower) equilibrium permafrost probabilities following a warming scenario.

or those that have well-developed transient layers (e.g. Shur et al., 2005) may be particularly resilient to small changes in MAAT (Froese et al., 2008), but lags will exist even for bedrock sites and/or lower ground ice contents. One source of both lags and uncertainty in this environment are thick organic mats, which are especially present in forested and lower elevation tundra zones. Providing they are not subject to removal by mechanisms such as forest fire or road construction, organic mats can result in lengthy lag times (Shur and Jorgenson, 2007) and can even sustain permafrost for short periods of MAAT $>0{ }^{\circ} \mathrm{C}$ (Williams and Smith 1989; Shur and Jorgenson, 2007). Another simplification in the scenario-based modelling is the uniform warming applied throughout the year. Most GCM (global circulation model) predictions for polar regions show that the majority of warming is likely to occur in the winter and autumn (IPCC, 2007; CAS, 2010). This winter warming can have significant impacts on permafrost degradation and thickening of the active layer as freeze-back is delayed in the fall (Burn and Zhang, 2010). Differential seasonal warming could potentially disrupt the patterns of SLRs throughout the region because the SLR is strongly correlated with the difference between mean 


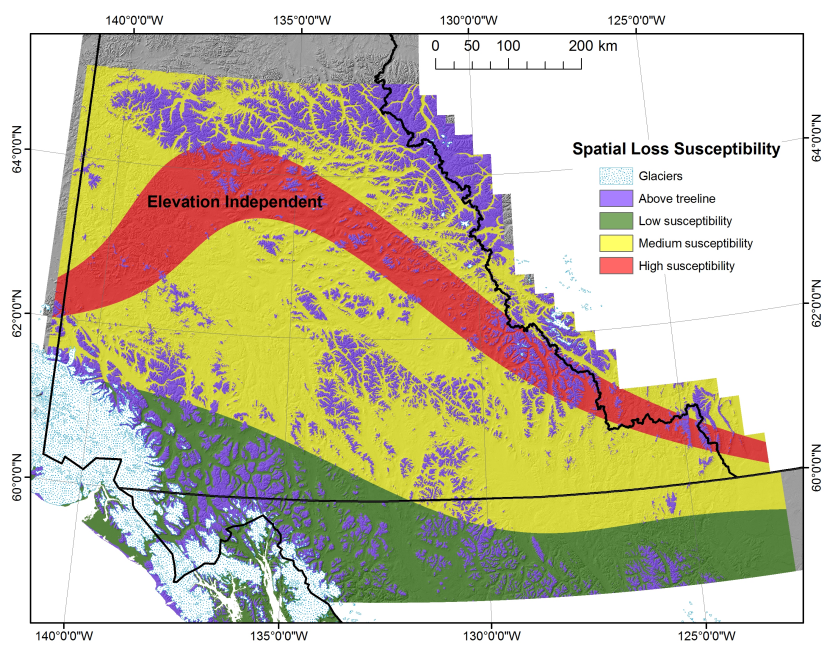

Fig. 15. Spatial loss susceptibility below treeline to small changes in MAAT (e.g. + $1 \mathrm{~K}$ ). Susceptibility is based on SLRs.

January and mean July air temperatures. Higher air temperature ranges (i.e. more continental environments) yield greater likelihoods of inversions below treeline, whereas lower ranges are present in more maritime climates with normal SLRs below treeline. The more pronounced the winter warming is relative to the summer, the smaller the range of temperatures. Consequently, the pattern of SLRs in the forest is likely to change, and in the most continental areas over the long term, the current BSL may be replaced by CUSL. In order to examine the effects of potential variable SLR change on the permafrost distribution in this region, statistically downscaled GCM data would be needed and a new equivalent elevation surface would have to be calculated that factored in the changed SLRs. There may also be secondary lags associated with treeline changes and the establishment of new SLRs in each of the sub-regions.

A final uncertainty relates to changes in the depth, characteristics, and distribution of the snowpack. Such changes are likely to accompany increases in MAAT and will also affect permafrost persistence. However, neither sub-grid variations in snow nor systematic change in snow cover can currently be incorporated into the regional model. Future work should attempt to minimize the uncertainties associated with these limitations in order to use the regional model to predict future permafrost distribution.

\section{Conclusions}

We conclude the following for the modelled area of discontinuous mountain permafrost in northwestern Canada:

1. The modelled extent of permafrost, $58 \%$ under the present-day mean annual air temperature field (1971-
2000), changes along a roughly exponential trend under spatially uniform raising or lowering of MAAT. Predicted permafrost extent increases to $76 \%$ under a cooling of $-1 \mathrm{~K}$ and decreases progressively under warming to only $9 \%$ when a $+5 \mathrm{~K}$ warming scenario is applied. The greatest rate of predicted spatial change $(20 \%$ of the region $\mathrm{K}^{-1}$ ) is predicted between current conditions and a warming of $+1 \mathrm{~K}$.

2. The rates and patterns of permafrost change in relation to increasing air temperatures vary across the modelled region. The Extreme Southwest sub-region shows elevation-dependent simple unidirectional spatial loss as a single loss front moves uniformly up-mountain. Patterns of complex unidirectional spatial loss develop across most of the South and Mid sub-regions where the loss front moves up-mountain but with differing degrees of elevation dependence above and below treeline. In the most continental North sub-region, where surface lapse rates are inverted, bidirectional spatial loss occurs with a descending loss front below treeline, and an ascending loss front above treeline.

3. The areas most susceptible to permafrost's spatial change as a response to MAAT perturbation are those where surface lapse rates are close to $0 \mathrm{~K} \mathrm{~km}^{-1}$. These areas are found below treeline in the North sub-region and are almost elevation independent so that a change in MAAT affects permafrost probabilities over a large range of elevations. Areas least susceptible to spatial change include all areas above treeline where SLRs are normal $\left(-6.5 \mathrm{~K} \mathrm{~km}^{-1}\right)$ and elevation-dependent sites below treeline

4. The methodology applied in this study could be used with other empirical-statistical permafrost models, such as those for European mountains, to examine the effects of equilibrium climate change on permafrost. Change modelling is driven through altering the equivalent elevation field and requires knowledge of local surface lapse rates.

5. Limitations of the modelling include that it predicts potential changes as a response to MAAT for equilibrium conditions and does not take into account transient effects, differential lag times or the impact of associated environmental changes, such as to snow or vegetation. In addition the warming/cooling, the scenarios applied assume uniform change through the seasons which is not predicted by GCMs. Non-uniform warming would change the seasonal range of air temperatures which correlates with the pattern of surface lapse rates. Future research should examine the sensitivity of the model to such spatial change.

6. The perturbed model can be used to predict the patterns of potential permafrost loss under different scenarios 
of MAAT increase, thereby assisting community climate adaptation planning as well as resource and linear infrastructure-route planning in the region. The modelling also reveals the potential pattern of changes in permafrost distribution in this area of complex topography, which is a key factor in examining hazards associated with permafrost degradation, especially on slopes.

Acknowledgements. This project was supported financially by the Canadian Foundation for Climate and Atmospheric Sciences, the Federal Government of Canada's International Polar Year Program, the Natural Sciences and Engineering Research Council of Canada, the Northern Scientific Training Program (Department of Indian Affairs and Northern Development), the Yukon Geological Survey, the Geological Survey of Canada, and the Faculty of Arts, University of Ottawa. The senior author is grateful for support from the Robert Gilbert Post-doctoral fellowship received from the Department of Geography at Queen's University during the writing of this paper.

Edited by: T. Zhang

\section{References}

ACGR: Glossary of Permafrost and Related Ground-Ice Terms, National Research of Canada, Technical Memorandum No. 142. pp. 64, 1988.

ACIA (Arctic Climate Impact Assessment) Cambridge: Cambridge University Press. 1042 p., available at: http://www.acia.uaf.edu, 2005.

Bonnaventure, P. P. and Lamoureux, S. F.: The active layer: a conceptual review of monitoring, modelling techniques and changes in a warming climate, Prog. Phys. Geogr., 37, 352-376, doi:10.1177/0309133313478314, 2013.

Bonnaventure, P. P. and Lewkowicz, A. G.: Mountain permafrost probability mapping using the BTS method in two climatically dissimilar locations, northwest Canada, Can. J. Earth Sci., 45, 443-455, doi:10.1139/E08-013, 2008.

Bonnaventure, P. P. and Lewkowicz, A. G.: Modelling climate change effects on the spatial distribution of mountain permafrost at three sites in northwest Canada, Clim. Change, 105, 293-312, doi:10.1007/s10584-010-9818-5, 2010.

Bonnaventure, P. P. and Lewkowicz, A. G.: Permafrost probability modelling above and below treeline, Yukon, Canada, Cold Reg. Sci. Technol., 79-80, 92-106, doi:10.1016/j.coldregions.2012.03.004, 2012a.

Bonnaventure, P. P., Lewkowicz, A. G., Kremer, M., and Sawada M. C.: A permafrost probability model for the southern Yukon and northern British Columbia, Canada, Permafrost Periglac. Proc., 23, 52-68, doi:10.1002/ppp.1733, 2012b

Burn, C. R.: Permafrost, tectonics, and past and future regional climate change, Yukon and adjacent Northwest Territories, Can. J. Earth Sci., 31, 182-191, doi:10.1139/e94-015, 1994.

Burn, C. R. and Nelson F. E.: Comment on "A projection of severe near-surface permafrost degradation during the 21 st century" by
David M. Lawrence and Andrew G. Slater, Geophys. Res. Lett., 33, L21503, doi:10.1029/2006GL027077, 2006.

Burn, C. R. and Zhang, Y.: Sensitivity of active-layer development to winter conditions north of treeline, Mackenzie delta area, western Arctic coast, 6th Canadian Permafrost Conference, Calgary, Canada, 2010

CAS (Canadian Standards Association): Technical guide: Overview of key considerations relating to community infrastructure, permafrost and climate change, Canadian standards association, Mississauga, Ontario, Canada, 2010.

Clements, C. B., Whiteman, C. D., and Horel, J. D.: Cold-air pooling structure and evolution in a mountain basin: Peter Sinks, Utah, J. Appl. Meteorol., 42, 752-768, 2003.

Dorren, L. K. A.: A review of rockfall mechanics and modelling approaches, Prog. Phys. Geogr., 27, 69-87, doi:10.1191/0309133303pp359ra, 2003.

Duk-Rodkin, A.: Surficial geology, Dawson, Yukon Territory. Geological Survey of Canada, open file 3288, 1:250 000 scale, 1996.

Evans, S. G. and Clague, J. J.: Recent climatic change and catastrophic geomorphic processes in mountain environments, Geomorphology, 10 107-128, doi:10.1016/0169-555X(94)90011-6, 1994.

Eyles, N. and Miall, A.: Canada Rocks, The Geologic Journey. Fitzhenry and Whiteside limited, Markham Ontario, 2007.

Farnell, R., Hare, P. G., Blake, E., Bowyer, V., Schweger, C., Greer, S., and Gotthardt, R.: Multidisciplinary investigations of alpine ice patches in Southwest Yukon, Canada, Arctic 57, 247-259, 2004.

Froese, D. G., Westgate, J. A., Reyes, A. V., Enkin, R. J., and Preece, S. J.: Ancient permafrost and a future, warmer arctic, Science, 321, 1648, doi:10.1126/science.1157525, 2008.

Global Terrestrial Network for Permafrost (GTNP database) http: //www.gtnp.org/ last access: June, 2011, 2011.

Gruber, S. and Haeberli, W.: Mountain permafrost, in: Permafrost Soils, edited by: Margesin, R., Biology Series Vol. 16, Springer, 33-44, doi:10.1007/978-3-540-69371-0_3, 2009.

Gruber, S. and Hoelzle, M.: Statistical modeling of mountain permafrost distribution: Local calibration and incorporation of remotely sensed data, Permafrost Periglac. Proc., 12, 69-77, doi:10.1002/ppp.374, 2001.

Haeberli, W., Guodong, C., Gorbunov, A. P., and Harris, S. A.: Mountain permafrost and climatic change, Permafrost Periglac. Proc., 4, 165-174. 1993.

Haeberli, W., Hallet, B., Arenson, L., Elconin, R., Humlum, O., Kääb, A., Kaufmann, V., Ladanyi, B., Matsuoka, N., Springman, S., and Vonder Mühll, D.: Permafrost creep and rock glacier dynamics, Permafrost Periglac. Proc., 17, 189-214, doi:10.1002/ppp.561, 2006.

Harris, C., Davies, M. C. R., and Etzelmüller, B.: The assessment of potential geotechnical hazards associated with mountain permafrost in a warming global climate, Permafrost Periglac. Proc., 12, 145-156, doi:10.1002/ppp.376, 2001.

Heginbottom, J. R., Dubreuil, M. A., and Haker, P. T.: Canada Permafrost. (1:7,500,000 scale), in: The National Atlas of Canada, 5 Edn., sheet MCR 4177, Ottawa: National Resources Canada, 1995.

Hugelius, G., Kuhry, P., Tarnocai, C., and Virtanen, T.: Soil organic carbon pools in a periglacial landscape: a case study from the Central Canadian Arctic, Permafrost Periglac. Proc., 21, 16-29, 
doi:10.1002/ppp.677, 2010.

IPCC (Intergovernmental Pannel on Climate Change), http://www. ipcc.ch/ipccreports/assessments-reports.htm, 2007.

Isaksen, K., Hauck, C., Gudevang, E., Ødegård, R. S., and Sollid, J. L.: Mountain permafrost distribution in Dovrefjell and Jotunheimen, southern Norway, based on BTS and DC resistivity tomography data, Norsk Geografisk Tidsskrift-Norwegian Journal of Geography, 56, 122-136, doi:10.1080/002919502760056459, 2002

Janke, J. R.: Modelling past and future alpine permafrost distribution in the Colorado front range, Earth Surface Proc. Land., 30, 1495-1508, doi:10.1002/esp.1205, 2005.

Jorgenson, M. T., Racine, C. H., Walters, J. C., and Osterkamp, T. E.: Permafrost degradation and ecological changes associated with a warming climate in central Alaska, Clim. Change, 48, 551-579, 2001.

Kääb, A.: Remote sensing of permafrost-related problems and hazards. Permafrost Periglac. Proc., 19, 107-136, doi:10.1002/ppp.619, 2008.

Kneisel, C., Rothenbuhler, C., Keller, F., and Haeberli, W.: Hazard assessment of potential periglacial debris flows based on GISbased spatial modelling and geophysical field surveys: a case study in the Swiss Alps, Permafrost Periglac. Proc., 18, 259-268, doi:10.1002/ppp.593, 2007.

Kremer, M., Lewkowicz, A. G., Bonnaventure, P. P., and Sawada, M. C.: Utility of classification and regression tree analyses and vegetation in mountain permafrost models, Yukon Territory, Canada, Permafrost Periglac. Proc., 22, 163-178, doi:10.1002/ppp.719, 2011.

Lawrence, D. M., Slater, A. G., Romanovsky, V. E., and Nicolsky, D. J.: Sensitivity of a model projection of nearsurface permafrost degradation to soil column and representation of soil organic matter, J. Geophys. Res., 113, F02011, doi:10.1029/2007JF000883, 2008.

Lewkowicz, A. G. and Bonnaventure, P. P.: Interchangeability of mountain permafrost probability models, Northwest Canada, Permafrost Periglac. Proc., 19, 49-62, doi:10.1002/ppp.612, 2008.

Lewkowicz, A. G. and Bonnaventure, P. P.: Equivalent elevation: a new method to incorporate variable lapse rates into mountain permafrost modelling, Permafrost Periglac. Proc., 22, 153-162, doi:10.1002/ppp.720, 2011

Lewkowicz, A. G., Bonnaventure, P. P., Smith, S. L., and Kuntz, Z.: Spatial and thermal characteristics of mountain permafrost, Northwest Canada, Geografiska Anna., 94, 195-213, doi:10.1111/j.1468-0459.2012.00462.x, 2012.

Lewkowicz, A. G. and Ednie, M.: Probability mapping of mountain permafrost using the BTS method, Wolf Creek, Yukon Territory, Canada, Permafrost Periglac. Proc., 15, 67-80, doi:10.1002/ppp.480, 2004.

Lewkowicz, A. G. and Harris, C.: Frequency and magnitude of active-layer detachment failures in discontinuous and continuous permafrost, northern Canada, Permafrost Periglac. Proc., 16, 115-130, doi:10.1002/ppp.522, 2005.

Lipovsky, P. S., Coates, J., Lewkowicz, A. G., and Trochim, E.: Active-layer detachments following the summer 2004 forest fires near Dawson City, Yukon, in: Yukon Exploration and Geology 2005, edited by: Emond, D. S.,Weston, L. H., Bradshaw, G. D., and Lewis, L. L., Yukon Geological Survey, 2006.
Natural Resources Canada: Forest ecosystems of Canada, http: //ecosys.cfl.scf.rncan.gc.ca/classification/classif08-eng.asp, last access: June, 2010, 2010.

O’Donnell, J. A., Harden, J. W., McGuire, A. D., and Romanovsky, V. E.: Exploring the sensitivity of soil carbon dynamics to climate change, fire disturbance and permafrost thaw in black spruce ecosystems, Biosciences, 8, 1367-1382, doi:10.5194/bg-8-13672011, 2011.

Page, A.: M.Sc. Thesis, A topographic and photogrammetric study of rock glaciers in the southern Yukon Territory, 2009.

Pagès, M. and Miró, J. R.: Determining temperature lapse rates over mountain slopes using vertically weighted regression: a case study from the Pyrenees, Meteorol. Appl., 17, 53-63, doi:10.1002/met.160, 2009.

Romanovsky, V. E., Smith, S. L., and Christiansen, H. H.: Permafrost thermal state in the polar northern hemisphere during the International Polar Year 2007-2009: a synthesis, Permafrost Periglac. Proc., 21, 106-116, doi:10.1002/ppp.689, 2010.

Shur, Y., Hinkel, K. M., and Nelson, F. E.: The transient layer: implications for geocryology and climate-change science, Permafrost Periglac. Proc., 16, 5-17, doi:10.1002/ppp.518, 2005.

Shur, Y. and Jorgenson, M. T.: Patterns of permafrost formation and degradation in relation to climate and ecosystems, Permafrost Periglac. Proc., 18, 7-19, doi:10.1002/ppp.582, 2007.

Smith, M. W. and Riseborough, D.: Climate and the limits of permafrost: a zonal analysis, Permafrost Periglac. Proc., 13, 1-15, doi:10.1002/ppp.410, 2002.

Smith, S. L., Romanovsky, V. E., Lewkowicz, A. G., Burn, C. R., Allard, M., Clow, G. D., Yoshikawa, K., and Throop, J.: Thermal state of permafrost in North America - a contribution to the International Polar Year, Permafrost Periglac. Proc., 21, 117-135, doi:10.1002/ppp.690, 2010.

SWIPA (Snow, Water, Ice Permafrost in the Arctic): www.amap.no/ swipa, 2012.

Tarnocai, C., Canadell, J. G., Schuur, E. A. G., Kuhry, P., Mazhitova, G., and Zimov, S.: Soil organic carbon pools in the northern circumpolar permafrost region, Global Biogeochemical Cycles, 23, 11, doi:10.1029/2008GB003327, 2009.

Wahl, H. E., Fraser, D. B., Harvey, R. C., and Maxwell, J. B.: Climate of Yukon, Canadian Government Publishing Centre, 1987.

Williams, P. J. and Smith, M. W.: The Frozen Earth: Fundamentals of Geocryology Cambridge University Press. 1989.

Woo, M. K., Kane, D. L., Carey, S. K., and Yang, D.: Progress in permafrost hydrology in the new millennium, Permafrost Periglac. Proc., 19, 237-254, doi:10.1002/ppp.613, 2008.

Youngblut, D. K. and Luckman, B. H.: Maximum June-July temperatures in the southwest Yukon over the last 300 years reconstructed from tree-rings, Dendrochronologia, 25, 153-66, doi:10.1016/j.dendro.2006.11.004, 2008. 